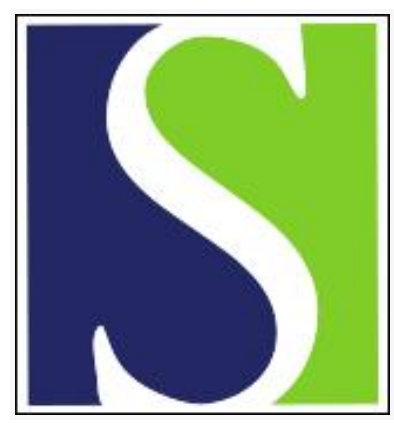

Scand J Work Environ Health 2013;39(4):361-368

https://doi.org/10.5271/sjweh.3342

Published online: 07 Jan 2013, Issue date: 01 Jul 2013

\title{
Shift work and long-term injury among police officers
}

by Violanti JM, Fekedulegn D, Andrew ME, Charles LE, Hartley TA, Vila B, Burchfiel CM

Longer term police injury leave may be indicative of serious injury and strain police budgets and personnel. This study was among the first to associate police injury duration across shifts, reduced sleep time, and workload. Sleep education and shift arrangement policies are necessary to help reduce on extended duty injuries among police.

Affiliation: Social and Preventive Medicine, School of Public Health and Health Professions, University at Buffalo, the State University of New York, Buffalo, NY, 14214, USA. violanti@buffalo.edu

Refers to the following text of the Journal: 2011;37(3):173-185

The following article refers to this text: 2015;41(6):542-553

Key terms: accident prevention; atypical work hour; injury; law enforcement; long-term injury; occupational injury; police; police officer; shift work; work history

This article in PubMed: www.ncbi.nlm.nih.gov/pubmed/23503596

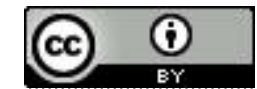




\title{
Shift work and long-term injury among police officers
}

\author{
by John M Violanti, PhD, ${ }^{1}$ Desta Fekedulegn, PhD, ${ }^{2}$ Michael E Andrew, PhD, ${ }^{2}$ Luenda E Charles, PhD, \\ MPH, ${ }^{2}$ Tara A Hartley, PhD, MPA, ${ }^{2}$ Bryan Vila, PhD, ${ }^{3}$ Cecil M Burchfiel, PhD, MPH ${ }^{2}$
}

\author{
Violanti JM, Fekedulegn D, Andrew ME, Charles LE, Hartley TA, Vila B, Burchfiel CM. Shift work and long-term \\ injury among police officers. Scand J Work Environ Health. 2013;39(4):361-368. doi:10.5271/sjweh.3342
}

Objective Our previous work has suggested that the incidence of any occurrence of injury leave among police officers is higher on night shifts. In this study, we extended our inquiry to determine whether the incidence of long-term injury leave varies across shifts.

Methods Police officers $(\mathrm{N}=419)$ from an urban department were included in the analysis. Daily payroll work history data from 1994-2010 was collected. Injury leave duration was examined ranging from $\geq 1-\geq 90$ days Poisson regression models were used to compute incidence rates (IR) and incidence rate ratios (IRR) of longterm injury.

Results Cumulative incidence of injury for different durations of leave defined as $\geq 1, \geq 5, \geq 10, \geq 15, \geq 30$, and $\geq 90$ days were $61.3 \%, 45.4 \%, 39.9 \%, 33.9 \%, 26.5 \%$, and $9.6 \%$ respectively. Age-and gender adjusted IRR of long-term injury ( $\geq 90$ days) for night versus day shifts was IRR 3.12, $95 \%$ confidence interval $(95 \% \mathrm{CI})$ 1.35-7.21 and IRR $2.21,95 \%$ CI 1.04-4.68, for night versus afternoon shifts. Among all durations examined, the largest IRR was for injury $\geq 90$ days, night versus day shifts (IRR 3.12, 95\% CI 1.35-7.21).

Conclusions Night shift work was significantly associated with long-term injury among police officers after adjustment for age and gender. Although type of injury was not available, it is possible that variation in injury type across shifts might account for some of this association.

Key terms accident prevention; atypical work hour; law enforcement; occupational injury; work history.

There appears to be a high rate of duty leave due to injury among protective workers in the United States. According to the US Bureau of Labor Statistics, protective service occupations had a median number of 15 days off per year due to injury compared to 7 days off in the private sector (1). Police officers are a large part of this occupational group. Injuries that resulted in police officers' lost time from work were similar to those of firefighters (38\% versus 39\% respectively) (2). In a study of 698 police departments in 2008 , there were over 2800 injuries and more than 24000 lost workdays, averaging 7.7 injuries and 66.4 lost workdays per agency (3).

Fatigue-related impairments due to circadian disruption can affect police officer performance and decision- making thus increasing the risk of serious injury (4-12). Decision-making may be particularly vulnerable to sleep loss, which impairs regions of the brain critical for decision-making required in fast-paced, ambiguous, high-risk police situations (13). Additionally, extended evening and night shifts are inherently more active than day shifts because more crimes occur during these hours and there are greater - and more hazardous - calls for service (14).

Wagsstaff \& Sigstad (4) found that work periods $\geq 8$ hours carried an increased risk of accidents, and the increased risk of accidents at around 12 hours of work was twice the risk at 8 hours. In a review of eight studies, Salminen (9) showed that the risk of occupational injury was $41 \%$ higher for 10 - compared to 8 -hour

1 Department of Social and Preventive Medicine, School of Public Health and Health Professions, University at Buffalo, The State University of New York, Buffalo, NY, USA

2 Biostatistics and Epidemiology Branch, Health Effects Laboratory Division, National Institute for Occupational Safety and Health, Centers for Disease Control and Prevention, Morgantown, WV, USA

3 Department of Criminal Justice and Criminology, and Sleep and Performance Research Center, Washington State University, Spokane, WA, USA.

Correspondence to: John M. Violanti, Social and Preventive Medicine, School of Public Health and Health Professions, University at Buffalo, the State University of New York, Buffalo, NY, 14214, USA. [E-mail: violanti@buffalo.edu] 
working days. In addition, reported injuries tended to be more serious and of longer duration on night shifts (9, 15). The risk of injury increased over successive night shifts so that the fourth night shift carried $36 \%$ more risk than the first (16).

\section{Present study}

In our previous work, we found that the incidence of injury was associated with night shift work among police officers (17). However, little is known about the length of time off due to injury and how this may vary across different shifts. Longer term injuries may be indicative of more serious types of injury and can put a strain on police personnel who have to cover duties for injured officers. The objective of the present study was to extend our previous analysis by assessing the duration of injury associated with shift work. We examined extended time off work due to on-duty injury on two levels. First, we examined officers who were on leave for more than $\geq 90$ days. These were considered "long-term injuries" by the department. Second, we examined injury leave at injury durations $\geq 1, \geq 5, \geq 10, \geq 15, \geq 30$ days to determine the incidence of injury at different time intervals and across shifts. The basic proposition was that night shift workers will have the greatest incidence of extended injury $(\geq 90$ days to long-term disability).

\section{Methods}

\section{Study population}

The Buffalo Cardio-Metabolic Occupational Police Stress (BCOPS) Study is a cross-sectional study designed to examine associations between physiological biomarkers of stress, subclinical metabolic and vascular disease markers, lifestyle, and psychosocial symptomatology among police officers. A total of 710 police officers in the Buffalo police department, a mid-sized urban police department in New York, were invited to participate in examinations from 4 June 2004 to 2 October 2009. Among officers invited, 464 completed examinations for the BCOPS study. The Internal Review Board of the State University of New York at Buffalo and the Human Subjects Review Board of the National Institute for Occupational Safety and Health approved this study. Data collection was performed at the Center for Preventive Medicine, State University of New York at Buffalo.

\section{Measures}

Questionnaires were administered to collect demographic and lifestyle information including age, gender, education, race/ethnicity, police rank, years of service, alcohol consumption, marital status, smoking status, hours of physical activity and sleep, and select physical measures. Trained technicians obtained anthropometric measurements that included height, weight, abdominal height, and waist circumference. Average hours of sleep in the past week were obtained during weekdays and weekends separately. Then average self-reported sleep duration per 24 hours in the past week was derived based on the weighted average over five weekdays and two weekend days. Hours of physical activity were assessed using the 7-day physical activity recall questionnaire.

Day-to-day work history data for a period of 16 years (1994-2010) were available for participating officers from computerized payroll records. The data contained an account of shifts, activity type, leave, sickness or injury information, and hours worked for each officer. Participants were classified according to the time they started their shift: (i) day shift (04:00-11:59 hours); afternoon shift (12:00-19:59 hours); and night shift (20:00-03:59 hours). The majority of officers started their shift at the following times: 08:00, 16:00, and 21:00 hours, and officers were scheduled on 10-hour permanent shifts. Total hours worked as well as hours worked on the day, afternoon, and night shift were computed for each participant. The length of time a participant worked was determined from date of the first available work history data to date of exam or date of first injury, whichever occurred first. The exposure variable of interest - day, afternoon, or night shift - represents the shift a participant was assigned to on a specific day. To our knowledge, night shift organizational interventions, such as napping or sleep education, have not been employed with this sample (Buffalo, NY, Police Department correspondence).

The participants were followed for occurrence of first new injury. We chose to examine only first injuries based on the premise that first occurrence is often of greater interest for etiologic studies than subsequent occurrences in the same person because the first occurrence affects the rate of subsequent occurrences (18). Only injuries that occurred while officers were on duty were available. Injuries or accidents that occurred while traveling to and from work were considered outside duty hours and were unavailable. Duration of first injury was defined as the total number of days including weekends that a participant was on leave due to an on-duty injury and ended on the first day the participant returned to a full day of regular work. Long-term injury status in conjunction with person-hours until first injury or date of examination (whichever came first) was the primary outcome variable of interest. Duration of injury was classified using the following cut-off points: $\geq 90, \geq 30, \geq 15, \geq 10, \geq 5$, and $\geq 1$ days. Injury leave was considered to be long-term if the duration was $\geq 90$ days. Therefore, incidence of long- 
term injury ( $\geq 90$ days) was the main outcome variable of interest. For comparison purposes, we also examined incidence of injury leave for shorter durations: $\geq 1, \geq 5$, $\geq 10, \geq 15$, and $\geq 30$ days. The maximum time-off range was set at $\geq 90$ days because it represented a time point designated by the department as "long-term disability" and was indicative of serious injury.

To assess average hours of sleep per day, each participant was asked: "On average, how many hours did you sleep each night during the last five weekday nights?" A weighted average of the sleep hours during weekdays and weekends was used to estimate sleep hours per day. In most shift work situations, activity may vary in intensity across the 24-hour work day resulting in a different work environment across shifts $(4,15-16)$. To account for these differences, we assessed shift activity levels reported by officers across three self-report levels: (i) low work activity (precinct not busy, low crime area); (ii) moderate work activity (moderate complaint rate, average crime); and (iii) high work activity (very busy, frequent complaints, high crime area). The combined effect of activity levels and shifts was then calculated using low workload and day shift as the referent category because officers in this group were considered to be at lowest risk of injury. Similarly, the day shift and reporting $\geq 5$ hours of sleep was used as the referent group to compare the combined effect of sleep duration and shift on incidence of long-term injury.

\section{Data analysis}

Of the 464 participants examined, 430 had work history data from which shift work and injury information was assessed. Of the 430, 4 were prevalent cases of injury where the participants were on injury leave at the start of the work history records and 7 officers did not have regular work hours prior to their first injury; hence, these 11 subjects were excluded leaving 419 participants for analysis. Demographic and lifestyle characteristics of study participants were summarized using means for quantitative variables and percentages for categorical variables. These were stratified by dominant shift. Associations of potential confounders with shift work and long-term injury were examined. Dominant shift was defined as the shift in which a participant spent the largest percentage of his/her total regular work time during the observation period (from 1994 to date of exam or date of first injury, whichever came first). Chi-square tests were used to examine the association between dominant shift and categorical covariates, while analysis of variance (ANOVA) was used to compare mean values of continuous covariates across the dominant shift. A similar comparison of covariates was performed across categories of injury duration. The following steps were undertaken to cal- culate the incidence rate (IR) of long-term injury by shift; this was later verified using a statistical model: (i) person-time (total number of hours worked) at each of the three shifts was computed using work history data until the date of first injury, for those with new injury, and date of exam for those with no injury; (ii) the number of participants who contributed persontime toward each shift was determined; (iii) the number of participants with injury in each of the three shifts was determined; (iv) incidence rate of injury for each shift was computed as the number of participants with injuries in the specified shift divided by the total person-time for the shift and expressed per 100000 person-hours.

The IR of long-term injury by shift and the associated $95 \%$ confidence intervals $(95 \% \mathrm{CI})$ were calculated using Poisson regression for ungrouped data (19). The IR of long-term injury were then compared across the three shifts by computing incidence rate ratios (IRR) and the corresponding 95\% CI using the Poisson model. Unadjusted and age- and gender-adjusted associations between shift worked and incidence of long-term injury were estimated. To understand how time to injury varies by shift, we conducted survival analysis relating time to first long-term injury (in hours) to dominant shift of the participant during the observation period. For each participant, time to injury was calculated as the total number of hours worked at the regularly scheduled time from the first date of work history data to first date of injury (for those with injury) and date of examination. Preliminary analyses involving the role of sleep duration and workload on these associations were limited by small sample sizes in some categories. Statistical significance was assessed for all tests at the 5\% level except for interaction terms. All analyses were conducted using the SAS system, version 9.2 (SAS Institute, Cary, NC, USA).

\section{Results}

Associations of demographic and lifestyle characteristics of study participants with dominant shift are shown in table 1 . The study participants consisted of 312 men and 107 women and were on average 43 years old (range 27-70 years). The percentages of the 419 participants who worked dominantly on the day, afternoon, and night shifts were $41 \%, 32 \%$, and $27 \%$ respectively. Approximately $10 \%$ of the sample had extended injury ( $\geq 90$ days). Participants on the night shift were younger and more likely to be male, had fewer years of work experience, and were composed of a large percentage of patrol (84\%) compared to day shift officers. Only $2.4 \%$ of participants reported taking sleep medication and 
Table 1. Demographic and lifestyle characteristics of study participants by dominant shift, Buffalo Cardio-metabolic Occupational Police Stress (BCOPS) Study, 2004-2009. [SD=standard deviation; GED=general educational development]

\begin{tabular}{|c|c|c|c|c|c|c|c|c|c|c|c|c|c|}
\hline \multirow[t]{2}{*}{ Characteristics } & \multicolumn{4}{|c|}{ Day shift $(\mathrm{N}=174)$} & \multicolumn{4}{|c|}{ Afternoon shift $(\mathrm{N}=134)$} & \multicolumn{4}{|c|}{ Night shift $(\mathrm{N}=111)$} & \multirow[t]{2}{*}{ P-value a } \\
\hline & $\mathrm{N}$ & $\%$ & Mean & SD & $\mathrm{N}$ & $\%$ & Mean & SD & $\mathrm{N}$ & $\%$ & Mean & SD & \\
\hline $\begin{array}{l}\text { Gender } \\
\text { Women } \\
\text { Men }\end{array}$ & $\begin{array}{r}66 \\
108\end{array}$ & $\begin{array}{l}37.9 \\
62.1\end{array}$ & & & $\begin{array}{r}22 \\
112\end{array}$ & $\begin{array}{l}16.4 \\
83.6\end{array}$ & & & $\begin{array}{l}19 \\
92\end{array}$ & $\begin{array}{l}17.1 \\
82.9\end{array}$ & & & 0.01 \\
\hline $\begin{array}{l}\text { Race } \\
\text { White } \\
\text { Black } \\
\text { Hispanic }\end{array}$ & $\begin{array}{r}126 \\
43 \\
3\end{array}$ & $\begin{array}{r}73.3 \\
25.0 \\
1.7\end{array}$ & & & $\begin{array}{r}107 \\
22 \\
2\end{array}$ & $\begin{array}{r}81.7 \\
16.8 \\
1.5\end{array}$ & & & $\begin{array}{r}93 \\
17 \\
0\end{array}$ & $\begin{array}{r}84.6 \\
15.5 \\
0.0\end{array}$ & & & 0.12 \\
\hline $\begin{array}{l}\text { Work load } \\
\text { Low/moderate } \\
\text { High }\end{array}$ & $\begin{array}{r}64 \\
101\end{array}$ & $\begin{array}{l}38.8 \\
61.2\end{array}$ & & & $\begin{array}{l}54 \\
77\end{array}$ & $\begin{array}{l}41.2 \\
58.8\end{array}$ & & & $\begin{array}{l}27 \\
83\end{array}$ & $\begin{array}{l}24.6 \\
75.4\end{array}$ & & & 0.02 \\
\hline $\begin{array}{l}\text { Education } \\
\leq \text { High school/GED } \\
\text { College }<4 \text { years } \\
\text { College } \geq 4 \text { years }\end{array}$ & $\begin{array}{l}22 \\
97 \\
54\end{array}$ & $\begin{array}{l}12.7 \\
56.1 \\
31.2\end{array}$ & & & $\begin{array}{l}14 \\
70 \\
49\end{array}$ & $\begin{array}{l}10.5 \\
52.6 \\
36.8\end{array}$ & & & $\begin{array}{l}12 \\
63 \\
36\end{array}$ & $\begin{array}{l}10.8 \\
56.8 \\
32.4\end{array}$ & & & 0.85 \\
\hline $\begin{array}{l}\text { Marital status } \\
\text { Single } \\
\text { Married } \\
\text { Divorced }\end{array}$ & $\begin{array}{r}23 \\
129 \\
22\end{array}$ & $\begin{array}{l}13.2 \\
74.1 \\
12.6\end{array}$ & & & $\begin{array}{r}15 \\
101 \\
16\end{array}$ & $\begin{array}{l}11.4 \\
76.5 \\
12.1\end{array}$ & & & $\begin{array}{l}13 \\
79 \\
19\end{array}$ & $\begin{array}{l}11.7 \\
71.2 \\
17.1\end{array}$ & & & 0.77 \\
\hline $\begin{array}{l}\text { Smoking status } \\
\text { Current } \\
\text { Former } \\
\text { Never }\end{array}$ & $\begin{array}{l}26 \\
58 \\
88\end{array}$ & $\begin{array}{l}15.1 \\
33.7 \\
51.2\end{array}$ & & & $\begin{array}{l}21 \\
27 \\
85\end{array}$ & $\begin{array}{l}15.8 \\
20.3 \\
63.9\end{array}$ & & & $\begin{array}{l}21 \\
21 \\
69\end{array}$ & $\begin{array}{l}18.9 \\
18.9 \\
62.2\end{array}$ & & & 0.03 \\
\hline $\begin{array}{l}\text { Rank } \\
\text { Patrol officer } \\
\text { Sergeant/Lieutenant } \\
\text { Captain/Detective }\end{array}$ & $\begin{array}{l}93 \\
26 \\
55\end{array}$ & $\begin{array}{l}53.5 \\
14.9 \\
31.6\end{array}$ & & & $\begin{array}{l}88 \\
15 \\
30\end{array}$ & $\begin{array}{l}66.1 \\
11.3 \\
22.6\end{array}$ & & & $\begin{array}{r}93 \\
13 \\
5\end{array}$ & $\begin{array}{r}83.8 \\
11.7 \\
4.5\end{array}$ & & & 0.01 \\
\hline $\begin{array}{l}\text { Long-term injury } \\
\text { Yes ( } \geq 3 \text { months }) \\
\text { No (<3 months) }\end{array}$ & $\begin{array}{r}12 \\
162\end{array}$ & $\begin{array}{r}6.9 \\
93.1\end{array}$ & & & $\begin{array}{r}13 \\
121\end{array}$ & $\begin{array}{r}9.7 \\
90.3\end{array}$ & & & $\begin{array}{l}15 \\
96\end{array}$ & $\begin{array}{l}13.5 \\
86.5\end{array}$ & & & 0.18 \\
\hline $\begin{array}{l}\text { Sleep hours/night } \\
\leq 5 \\
\geq 5\end{array}$ & $\begin{array}{r}26 \\
146\end{array}$ & $\begin{array}{l}15.1 \\
84.9\end{array}$ & & & $\begin{array}{r}26 \\
107\end{array}$ & $\begin{array}{l}19.6 \\
80.4\end{array}$ & & & $\begin{array}{l}25 \\
85\end{array}$ & $\begin{array}{l}22.7 \\
77.3\end{array}$ & & & 0.26 \\
\hline $\begin{array}{l}\text { Sleep medication usage } \\
\text { Yes } \\
\text { No }\end{array}$ & $\begin{array}{r}5 \\
169\end{array}$ & $\begin{array}{r}2.9 \\
97.1\end{array}$ & & & $\begin{array}{r}3 \\
130\end{array}$ & $\begin{array}{r}2.3 \\
97.7\end{array}$ & & & $\begin{array}{r}2 \\
109\end{array}$ & $\begin{array}{r}1.8 \\
98.2\end{array}$ & & & 0.92 \\
\hline $\begin{array}{l}\text { Age (in years) } \\
\text { Body mass index }\left(\mathrm{kg} / \mathrm{m}^{2}\right)\end{array}$ & $\begin{array}{l}174 \\
173\end{array}$ & & $\begin{array}{l}46.0 \\
29.0\end{array}$ & $\begin{array}{l}8.0 \\
5.1\end{array}$ & $\begin{array}{l}134 \\
134\end{array}$ & & $\begin{array}{l}41.2 \\
29.9\end{array}$ & $\begin{array}{l}7.2 \\
4.8\end{array}$ & $\begin{array}{l}111 \\
111\end{array}$ & & $\begin{array}{l}39.1 \\
29.3\end{array}$ & $\begin{array}{l}6.7 \\
4.2\end{array}$ & $\begin{array}{l}0.01 \\
0.17\end{array}$ \\
\hline Physical activity (hours/week) & 173 & & 14.4 & 11.3 & 133 & & 16.6 & 15.5 & 109 & & 14.3 & 12.1 & 0.25 \\
\hline Average sleep (hours/day) & 172 & & 6.3 & 1.1 & 133 & & 6.3 & 1.3 & 110 & & 6.1 & 1.2 & 0.20 \\
\hline Drinks (number/week) & 170 & & 6.5 & 11.3 & 132 & & 6.0 & 10.4 & 110 & & 4.5 & 5.8 & 0.27 \\
\hline Years of service & 174 & & 19.1 & 8.5 & 133 & & 15.4 & 7.1 & 111 & & 11.5 & 6.1 & 0.01 \\
\hline
\end{tabular}

a P-values are from $\chi^{2}$ tests of independence or Fisher's exact test for categorical variables and from analysis of variance (ANOVA) testing differences in means across dominant shift for continuous variables.

its use did not vary across shifts $(\mathrm{P}=0.92)$. Participants with long-term injury leave ( $\geq 90$ days) were more likely to be single (unmarried), patrol officers, and current smokers and were engaged in more hours of physical activity per week (data not shown). In addition, those who were injured had fewer years of service than noninjured officers.

Table 2 shows the IR and IRR of long-term injury by shift work. Of the 419 participants, $9.6 \%(\mathrm{~N}=40)$ had long-term first injury during the observation period and the number of officers with injuries were 12,11, and 17 on the day, afternoon, and night shift, respectively. The association between shift work and long-term injury among police officers was statistically significant. After adjusting for age and gender, the IR of long-term injury for officers working on the night shift was 3 times more frequent than for those working on the day shift (IRR $3.12,95 \%$ CI $1.35-7.21, \mathrm{P}=0.01$ ), and 2.2 times more frequent than for those working on the afternoon shift (IRR 2.21, 95\% CI 1.06-4.68, $\mathrm{P}=0.04$ ). 
Table 2. Incidence rate (IR) and incidence rate ratio (IRR) of on-duty, long-term injury leave ( $\geq 90$ days) by shift, Buffalo Cardio-metabolic Occupational Police Stress (BCOPS) Study, 2004-2009. [95\% Cl=95\% confidence interval]

\begin{tabular}{|c|c|c|c|c|c|c|c|c|c|}
\hline \multirow[t]{2}{*}{ Shift } & \multirow[t]{2}{*}{$\begin{array}{l}\text { Number } \\
\text { at risk a }\end{array}$} & \multirow[t]{2}{*}{$\begin{array}{l}\text { Person } \\
\text { hours }{ }^{b}\end{array}$} & \multirow[t]{2}{*}{$\begin{array}{l}\text { Number } \\
\text { injured c }\end{array}$} & \multirow[t]{2}{*}{$\begin{array}{l}\text { IR per } 100000 \\
\text { person hours }\end{array}$} & \multirow[t]{2}{*}{$\begin{array}{l}95 \% \mathrm{Cl} \text { e } \\
\text { for IR }\end{array}$} & \multicolumn{2}{|c|}{ Unadjusted } & \multicolumn{2}{|c|}{$\begin{array}{c}\text { Age- and } \\
\text { gender-adjusted }\end{array}$} \\
\hline & & & & & & IRR & $95 \% \mathrm{Cl}$ & IRR & $95 \% \mathrm{Cl}$ \\
\hline Day & 412 & 2512333 & 12 & 0.48 & $0.27-0.86$ & & & & \\
\hline Afternoon & 405 & 1891469 & 11 & 0.59 & $0.15-2.37$ & & & & \\
\hline Night & 373 & 1273236 & 17 & 1.33 & $0.36-5.00$ & & & & \\
\hline Night versus day & & & & & & 2.76 & $1.30-5.83$ & 3.12 & $1.35-7.21$ \\
\hline Afternoon versus day & & & & & & 1.21 & $0.53-2.77$ & 1.42 & $0.54-3.71$ \\
\hline Night versus afternoon & & & & & & 2.27 & $1.06-4.87$ & 2.21 & $1.04-4.68$ \\
\hline
\end{tabular}

a The number of participants who contributed person-hours to that specific shift. Note that a participant can contribute person-hours to one, two, or all

three shifts but first serious injury occurs in only one of the three shifts.

${ }^{\mathrm{b}}$ The total number of hours of work at regularly scheduled time for each shift. This is the total time (in hours) at risk for first serious injury.

${ }^{c}$ The number of participants with first long-term injury (note that there were 13 officers with long-term injury who dominantly worked on afternoon shift (see table 1) but two of those were first injured while working on night shift leading to 11 cases for afternoon shift and $17(15+2)$ cases for the night shift.

d IR is computed as the number of participants with first serious injury divided by total person-hours for the shift and the result expressed in 100000 working hours.

${ }^{e}$ The $95 \% \mathrm{Cl}$ were computed using the Poisson regression model for ungrouped data.

\section{Comparing short- and long-term injury leave}

The first part of our analysis concerned the impact of shift work on long-term injury leave ( $\geq 90$ days). To further explore injury leave of shorter duration, we established injury leave criteria of $\geq 1, \geq 5, \geq 10, \geq 15$, and $\geq 30$ days off duty. The long-term injury criterion of $\geq 90$ days was included in the analysis in order to compare it with shorter durations.

Cumulative incidence of injury associated with duration of leave of $\geq 1, \geq 5, \geq 10, \geq 15, \geq 30$, and $\geq 90$ days were $61.3 \%, 45.4 \%, 39.9 \%, 33.9 \%, 26.5 \%$, and $9.6 \%$ respectively. Table 3 displays results for IRR of injury by shift at each duration category of time off duty. The IRR were significantly higher for officers on night compared with day shifts regardless of the duration of leave time (except for $\geq 10$ days). The largest IRR for night versus day (IRR 3.12, 95\% CI 1.35-7.21) and for night versus afternoon (IRR 2.21, $95 \%$ CI 1.06-4.68) were observed for long-term injury $\geq 90$ days.

\section{Discussion}

We compared the association of shift work with incidence rates of long-term injury leave among police officers using several definitions of injury leave time including long-term leave at $\geq 90$ days and a group of shorter duration leave times. The highest incidence of long-term injury ( $\geq 90$ days) was among officers who worked night shifts compared to those who worked day or afternoon shifts. The comparison of long-term injury leave ( $\geq 90$ days) with shorter durations $(\geq 1, \geq 5, \geq 10$, $\geq 15, \geq 30$ days) showed that the largest IRR for night versus day (IRR 3.12, 95\% CI 1.35-7.21) and night versus afternoon (IRR $2.21,95 \%$ CI 1.06-4.68) were observed for long-term injury ( $\geq 90$ days), indicating that officers on night shift had a greater risk of long- than short-term injury.

These findings suggest that working night shifts not only increases the incidence of injury as noted in our previous work, but also increases the likelihood of long-term injury ( $\geq 90$ days). It follows that longer time periods off from work may be indicative of more serious injury. Our results showed that approximately $34 \%$ of officers who worked night shifts were off duty $\geq 15$ days - twice the rate of the Bureau of Labor Statistics reported national median of 15 days (1).

\section{Strengths and limitations}

While previous studies have suggested that injuries to police officers occur more frequently on night shifts, they rely heavily on self-reported shift work data. We were instead able to examine shifts systematically based on multiple years of objective, day-to-day actual work records of officers. We were also able to take into account differences in age and gender across shifts.

Although our total sample size included 419 officers, some categories were limited in size. There were also only 40 officers who sustained a long-term injury ( $\geq 90$ days). It is possible that a form of selection bias could have existed. However, the distribution of dominant shift (day, afternoon, and night) and the occurrence of long-term injury did not vary significantly between study participants and non-responders $(\mathrm{P}=0.41$ and $\mathrm{P}=0.28$, respectively, based on the Chi-square test). 
Table 3. Age- and gender-adjusted incidence rate ratio (IRR) of long-term injury leave by shift and criteria used to define long-term injury among 419 police officers. [ $95 \% \mathrm{Cl}=95 \%$ confidence interval]

\begin{tabular}{|c|c|c|c|c|c|c|c|}
\hline \multirow{2}{*}{$\begin{array}{l}\text { Criteria for long-term injury (dura- } \\
\text { tion of leave in days) }\end{array}$} & \multirow{2}{*}{$\frac{\text { Cases }}{\mathrm{N}}$} & \multicolumn{2}{|c|}{ Night versus day } & \multicolumn{2}{|c|}{ Afternoon versus day } & \multicolumn{2}{|c|}{ Night versus afternoon } \\
\hline & & IRR & $95 \% \mathrm{Cl}$ & IRR & $95 \% \mathrm{Cl}$ & IRR & $95 \% \mathrm{Cl}$ \\
\hline$\geq 1$ & 257 & 1.75 & $1.26-2.45$ & 1.05 & $0.75-1.48$ & 1.66 & $1.23-2.24$ \\
\hline$\geq 5$ & 190 & 1.53 & $1.04-2.27$ & 1.08 & $0.73-1.60$ & 1.42 & $1.00-2.01$ \\
\hline$\geq 10$ & 167 & 1.40 & $0.93-2.13$ & 1.03 & $0.69-1.55$ & 1.36 & $0.94-1.97$ \\
\hline$\geq 15$ & 142 & 1.65 & $1.05-2.57$ & 1.04 & $0.66-1.62$ & 1.59 & $1.06-2.37$ \\
\hline$\geq 30$ & 111 & 1.82 & $1.09-3.04$ & 1.23 & $0.74-2.04$ & 1.48 & $0.94-2.33$ \\
\hline$\geq 90$ & 40 & 3.12 & $1.35-7.21$ & 1.42 & $0.54-3.71$ & 2.21 & $1.04-4.68$ \\
\hline
\end{tabular}

We had limited data on possible additional factors that may influence injury. For example, the number of average hours of sleep per 24-hour period was collected from officers but was only available at the time of the clinic visit. Sleep hours were dichotomized at $\leq 5$ and $\geq 5$ hours in accordance with Belenky et al's (20) recommended sleep restriction performance bifurcation values. Although the number of participants was limited in several categories, officers who worked the night shift and reported $\leq 5$ hours of sleep ( 4 cases $/ 25$ at risk) had an age and gender-adjusted long-term injury rate 4.5 times greater (IRR 4.45, 95\% CI 1.47-13.53, $\mathrm{P}=0.01$ ) than those who worked the day shift and reported $\geq 5$ hours of sleep ( 9 cases/149 at risk). Lack of sleep can affect cognitive abilities. Killgore et al $(21,22)$ found that sleep deprivation tended to impair the ability to use past experiences to guide decision-making and increase risky choices. Sleep deprivation also tended to slow the ability to make choices that are emotionally charged and to increase propensity to accept controversial solutions to dilemmas. (23).These factors may lead to more frequent and possibly more serious injuries at work. A recent study by Rajaratnam et al (24) reported that even two hours loss of sleep is associated with decrements in performance. Sleep disorders resulting in chronic sleep deficiency may therefore adversely affect job performance and increase accident risk.

In most shift work situations, activities performed may vary in intensity (workload) across the 24-hour work day resulting in a different work environment across shifts $(16,25)$. While we did not have longterm data on workload, we were able to collect information at the time of the officer's visit to the clinic. Workload was subjectively described as high, moderate, or low. Officers with high activity levels who worked on night shifts experienced a higher incidence of extended time off duty due to injury. The age- and gender-adjusted IRR for long-term injury was nearly five times larger (IRR 4.61, 95\% CI 1.45-14.86) for the combination of "high activity and night shift" (13 cases $/ 83$ at risk) compared to "low activity and day shift" (6 cases/64 at risk). In a night shift environment of high demands and increased workload, the outcome of psychological strain along with circadian disruption can result in increased physical and mental fatigue and the risk of more injury or accidents (21). Results involving sleep duration and workload are based on a small number of cases as evidenced by the wide $\mathrm{CI}$ and hence should be interpreted with caution.

Lastly, data concerning types of injury were not available. However, police injuries can be characterized by previous research. A recent study on the extent to which police injuries changed from 1996-1998 to 2006-2008 reported that the largest proportion of incidents occurred as a result of controlling or arresting suspects (41.0\%). This category accounted for $69.6 \%$ of all incidents. The most common injuries in these incidents were bruise/black eye/contusion $(30.4 \%)$, bodily fluid contact (21.7\%), and human bites (15.6\%). Other common injuries in suspect-related incidents were cuts/punctures/abrasions/lacerations (26.8\%), sprains/ strains $(24.8 \%)$, and other muscle pain $(17.6 \%)$. The most common types of injuries associated with accidents were other muscle pain $(21.5 \%)$, sprain/strain $(18.1 \%)$, and contact with infectious disease/bodily fluid (18.6\%) (26). It was interesting that the authors of this study also concluded that younger officers are more likely to sustain an injury. Younger officers are generally more active and may put themselves in situations that result in injury. Although in the present study the majority of officers who worked on night shift were on average younger than those on other shifts, we adjusted for differences in age across shifts. Variability in the type of injury across shifts could account for some of the association of interest. For example, if certain types of injury that lead to longer duration of leave (eg, gunshot) are more commonly found on the night shift, then differences in long-term injury incidence across shifts that we report could be due to differences in the type of injury that occurs.

In conclusion, this study assessed the daily shift schedule and occurrence of injury leave over a 15 -year period among a cohort of police officers. The results show that, independent of age and gender, officers working on the night shift were at higher risk of injury leave compared to those on day or afternoon shifts. This 
increased risk of injury for night shift workers was largest for durations of injury leave lasting $\geq 90$ days.

Future research might take into account factors examined in this study in order to help prevent long-term injuries in this critical population. Longitudinal studies may help to determine the impact of working shifts over extended periods of time. The integration of frequency and duration of injuries would be an interesting and worthwhile consideration for future studies. In the present study, we focused only on occurrence of first injury. Additionally, objective measurement over time of sleep duration and workload would enhance understanding of the role these factors might play in influencing risk of future injury.

In a practical sense, shift design and proper sleep education may be of value in police injury prevention. In times of economic strife, decreased police budgets, and fewer police personnel, it is essential that officers remain free of injury and capable of performing their duties.

\section{Acknowledgments}

The National Institute for Occupational Safety and Health (NIOSH) (contract 200-2003-01580) and the National Institute of Justice (NIJ) (grant number: NIJ 2005-FS-BX-0004) supported this study.

The findings and conclusions in this article are those of the authors and do not necessarily represent the views of the NIOSH, the Center for Disease Control, or the NIJ.

\section{References}

1. Bureau of Labor Statistics. Census of fatal occupational injuries. Workplace injuries and illnesses- 2009. USDL-101451. 2010; http://www.bls.gov/. Accessed 21 May 2012.

2. Suyanna J, Rittenburger JC, Patterson PD, Hostler D. Comparison of public safety provider injury rates. Prehosp Emerg Care. 2009;13:451-5. http://dx.doi. org/10.1080/10903120903144908.

3. Zakhary YA. A zero tolerance approach to officer injuries. Police Chief. 2008;LXXV:1-6.

4. Wagstaff AS, Sigstad Lie J-A. Shift and night work and long working hours- a systematic review of safety implications. Scand J Work Environ Health. 2011;37:173-85. http://dx.doi. org/10.5271/sjweh.3146.

5. Vila BJ, Morrison GB, Kenney DJ. Improving shift schedule and work-hour policies and practices to increase police officer health, safety and performance. Police Quarterly. 2002;5:1:424. http://dx.doi.org/10.1177/109861102129197995.

6. Vila BJ, Samuels C. Sleep loss in police and implications for other first responders and the military. In: Kryger MH, Roth
T, Dement WC (editors). Principles and Practice of Sleep Medicine 5th Ed. (PPSM 5e), chapter 72. Walthham, MA: Elsevier; 2011.

7. Amendola KL, Weisburd D, Hamilton EE, Jones G, Slipka M. An experimental study of compressed work schedules in policing: advantages and disadvantages of various shift lengths. J Exp Criminol. 2011;7:3 (online pre-print). http:// dx.doi.org/10.1007/s11292-011-9135-7

8. Dembe AE, Erickson JB, Delbos RG. The impact of overtime and long work hours on occupational injuries and illnesses: new evidence from the United States. Occup Env Med. 2005;62:588-97. http://dx.doi.org/10.1136/ oem.2004.016667.

9. Salminen, S. Shift work and extended working hours as risk factors for occupational injury. Erg Open J. 2010;3:14-8.

10. Warm JS, Parasuraman R, Mathhews G. Vigilance requires hard mental work and is stressful. Human Factors. 2008;50:433-41. http://dx.doi.org/10.1518/001872008X312152.

11. Robb G, Sultana S Ameratunga S, Jackson R. A systematic review of epidemiological studies investigating risk factors for work-related road traffic crashes and injuries. Injury Prevention. 2008;14:51-8. http://dx.doi.org/10.1136/ ip.2007.016766

12. Houser AN, Jackson BA, Bartis JT, Peterson DJ. Emergency responder injuries and fatalities: An analysis of surveillance data. TR-100-NIOSH. Santa Monica, CA: RAND; 2004.

13. Durmer, JS, Dinges, DF. Neurocognitive consequences of sleep deprivation. Semin Neurol. 2005;25:117-129. http:// dx.doi.org/10.1055/s-2005-867080.

14. Brantingham P. Patterns in Crime. New York: Macmillan; 1984.

15. Oginski A, Oginska H, Pokorksi J, Kmita W, Gozdziela R. Internal and external factors influencing time related injury risk in continuous shift work. Int J Occup Safety Health. 2000;6:405-21.

16. Folkard S, Tucker P. Shift work, safety, and productivity. Occup Med. 2003;53:95-101. http://dx.doi.org/10.1093/ occmed/kqg047.

17. Violanti JM, Fekedulegn D, Andrew ME, Charles LE, Hartley TA, Vila B, Burchfiel CM. Shift work and the incidence of injury among police officers. Am J Ind Med. 2012;55:217-27. http://dx.doi.org/10.1002/ajim.22007.

18. Rothman, KJ, Greenland, S, Lash, TL. Modern Epidemiology, 3rd Edition. Boston (MA): Lippincott Willams \& Wilkins; 2008.

19. Loomis D, Richardson DB, Elliott L. Poisson regression analysis of ungrouped data. Occup Environ Med. 2005;62:3259. http://dx.doi.org/10.1136/oem.2004.017459.

20. Belenky G, Wesensten NJ, Thorne DR, Thomas ML, Sing HC, Redmond DP, Russo MB, Balkin TJ. Patterns of performance degradation and restoration during sleep restriction and subsequent recovery: a sleep dose-dependent study. J Sleep Res. 2003;12:1-12. http://dx.doi.org/10.1046/j.13652869.2003.00337.x.

21. Killgore WDS, Balkin TJ, Wesensten NJ. Impaired decision 
making following 49 hours of sleep deprivation. Journal of Sleep Research. 2006;15:7-13. http://dx.doi.org/10.1111/ j.1365-2869.2006.00487.x.

22. Killgore WDS, Kahn-Greene ET, Lipizzi EL, Newman RA, Kamimori GH, Balkin TJ. Sleep deprivation reduces perceived emotional intelligence and constructive thinking skills. Sleep Med. 2008;9:517-26. http://dx.doi.org/10.1016/j. sleep.2007.07.003.

23. Killgore WDS, Killgore DB, Day LM, Li C, Kamimori GH, Balkin TJ. The effects of 53 hours of sleep deprivation on moral judgment. Sleep. 2007;30:345-52.

24. Rajaratnam SMW, Barger LK, Lockley SW, Shea SA, Wang W, Landrigan CP, O’Brien CS, Qadri S, Sullivan JP, Cade BE,
Epstein LJ, White DP, Czeisler CA. Sleep disorders, health, and safety in police officers. JAMA. 2011;306:2567-78. http:// dx.doi.org/10.1001/jama.2011.1851.

25. Folkard S, Lombardi DA, Tucker PT. Shiftwork: Safety, sleepiness and sleep. Ind Health. 2005;43:20-3. http://dx.doi. org/10.2486/indhealth.43.20.

26. Brandl S, Stroshone MS. The Physical Hazards of Police Work Revisited. Police Quarterly. 2012; 15:262-82. http://dx.doi. org/10.1177/1098611112447757.

Received for publication: 25 July 2012 